\title{
Seasonal and positional variations in the rate of nacre coating in Indian pearl oyster Pinctada fucata (Gould, 1850)
}

\author{
R. Mary Rinjü, M. K. Anil and E. Sherly Williams ${ }^{1}$ \\ Research Centre of ICAR-Central Marine Fisheries Research Institute, Vizhinjam-695 521, Kerala, India. \\ 'Fatima Mata National College, Kollam-691 001, Kerala, India. \\ *Correspondence e-mail: rinjumary89@gmail.com
}

Received: 11 Oct 2017 Accepted: 22 June 2018 Published: 29 June 2018

Original Article

\begin{abstract}
Recently technology has been perfected for the production of quality image pearls (mabe pearls) in India which fetches a good price ranging from $\$ 20-50$ per pearl. This study focused on variations in the rate of nacre coating during different seasons when implanted with image pearl nucleus in different positions of the pearl oyster shell. The implantation was done at three positions at P1, P2 and P3 in both shells and the experiments were repeated in three seasons namely pre monsoon, monsoon and post monsoon. Among the positions, the position P2 which is the wide marginal mantle region gave the maximum nacre coating rate. Hydrological parameters such as atmospheric and water temperature, salinity, $\mathrm{pH}$, turbidity, ammonia, nitrite, nitrate, phosphate, silicate, dissolved oxygen, primary productivity and chlorophyll a were also recorded during the study. Rate of nacre coating was found to be maximum $(6.79 \pm 2.07 \mu /$ day) during post monsoon months corresponding to maximum productivity (Net Primary Production of $204.40 \pm 45.86 \mathrm{mgC} / \mathrm{m}^{3} /$ day and Gross Primary Production of $361.40 \pm 96.92 \mathrm{mgC} / \mathrm{m}^{3} /$ day) and chlorophyll concentration $\left(2.79 \pm 0.13 \mathrm{mg} / \mathrm{m}^{3}\right)$. The rate of coating was minimum $(2.19 \pm 0.17 \mu /$ day) during pre monsoon season. The influence of hydrological parameters and positions of the implanted nuclei on the nacre coating were statistically analysed and discussed in the present paper.
\end{abstract}

Keywords: Pinctada fucata, image pearls, mabe, nacre, seasonal variation, hydrology.

\section{Introduction}

The Akoya pearl oyster Pinctada fucata (Gould, 1850) is one of the pearl producing bivalves of the family Pteriidae, and the gem quality pearls it produces namely Akoya pearl of size range from $3 \mathrm{~mm}$ to $10 \mathrm{~mm}$ has a great demand. In India, the pearl oyster fishery existed in the areas of the Gulf of Mannar at Southeast coast and the Gulf of Kutch on the Northwest coast. The quality of pearl depends on the sheen quality of nacre secreted by the oyster and thickness of its nacreous layers. Image pearls are produced by implanting a nuclei or mould which is prepared from the shell based cement; using metal templates of required shape, against the inside shell rather than the soft tissue of an oyster. Oyster then secretes layers of lustrous coat over the image nuclei producing an image pearl which is sawed off from the shell and used in 
pendants, studs, brooches or rings (Anil et al., 2007) (Fig. 1). They can be made in different size and shapes, but figurines of gods and goddesses covered with natural pearly (nacre coating) are preferred.

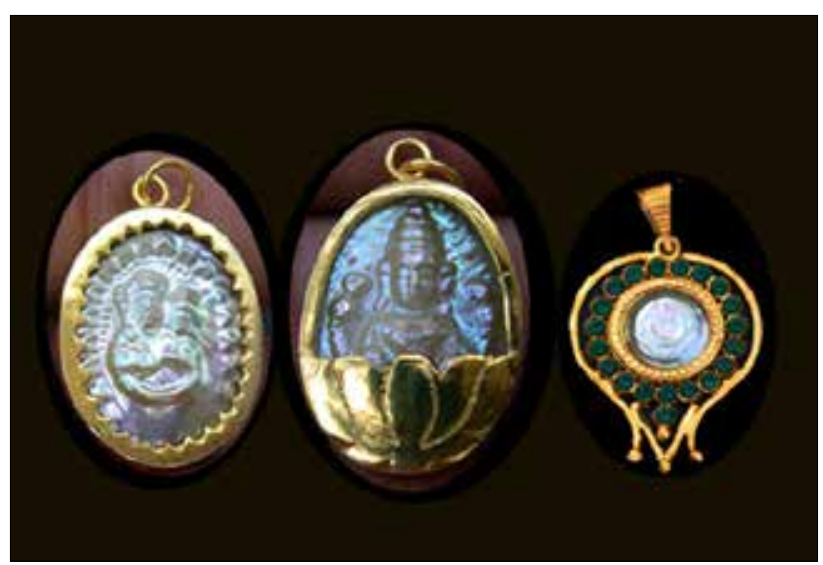

Fig. 1. Different types of image pearls.

Extensive research work was carried out on different aspects of the oysters of Pinctada fucata including, seed production, growth, fouling, nacre production and inheritance of shell characters (Shirai, 1970; Alagarswami, 1991; Gervis and Sims, 1992; Velayudhan et al., 1996; Wada and Kamaru, 1996; Kripa et al., 2007). Researchers had demonstrated the correlation between shell growth and pearl quality (Mizuno, 1983; Coeroli and Mizuno, 1985). Previous studies on the pearl production in $P$. fucata revealed that the factors such as diameter of nucleus (Dharmaraj and Sukumaran, 2003a, b; Shirai, 1970; Saucedo et al., 1998), number of nuclei (Alagarswami, 1991), location of the nuclei (Saucedo et al., 1998) and farm site (Alagarswami, 1991; Victor et al., 2003), depth of the farm site (Jagadis et al., 2003), have significant effect on the nacre secretion and pearl quality.

In India, for the first time a technique for image pearl production was developed by Mohamed et al. (2003) using base images. They used specially fabrictad metallic dies for obtaining the required designs and the ingredients used were mixture of molluscan shell powder and resin glue for making image nuclei. Implantation was done by sliding the base images through under the mantle at specific locations (Mohamed et al., 2003; 2011). Vizhinjam Research Centre of CMFRI has developed a simple and unique technique for the production of mabe/image pearls. They also have standardized techniques for the production of image/mabe pearl nucleus and quality image pearl size up to $20 \mathrm{~mm}$ (Anil et al., 2003; 2007). Saucedo et al. (1998) conducted research on the pearl oysters of species Pinctada mazatlantica (Hanley, 1856) and Pteria sterna (Gould, 1851) in order to determine the number, size and location of nuclei that could be implanted in oysters for mabe pearl production. Experimental studies carried out by
Kripa et al. (2008) had demonstrated suitable technology for designer mabe pearl production in Pinctada margaretifera and Pteria penguin.

No previous studies were attempted on the seasonal changes in the rate of nacre coating in $P$. fucata along the south west coast of India and the present study was conducted to elucidate seasonal variations in nacre coating of $P$. fucata in different positions of both shell valves and to explicate the effect of main hydrological parameters on the rate of nacre coating. Study focused on the thickness of the nacre secreted on the mabe pearl nucleus implanted in different positions in both right and left shell valves in three seasons' viz., pre monsoon, monsoon and post monsoon in relation with the hydrology of Vizhinjam waters.

\section{Material and methods}

The study was conducted in Vizhinjam bay of Kerala Coast which is situated on the Southwest coast of India (Long. 76 ${ }^{\circ} 9^{\prime} \mathrm{E}$, Lat. $8^{\circ} 22^{\prime} 30^{\prime \prime} \mathrm{N}$ ). The depth of the bay varies from 10 to 15 meters and the bottom of bay is sandy. Trials were conducted using hatchery bred and farm grown adult oysters of one year and six months old with an average dorsoventral measurement (DVM ) of $62 \mathrm{~mm}$, hinge length (HL) of $57 \mathrm{~mm}$ and weight of $28 \mathrm{~g}$, which were selected from those cultured in box cages.

Adult oysters were collected and cleaned off fouling organisms before implantation. Right and left shell valves of the oysters were divided as $\mathrm{P} 1, \mathrm{P} 2$ and $\mathrm{P} 3$ with corresponding angles of $45^{\circ}(\mathrm{P} 1)$, $90^{\circ}$ (P2) and $125^{\circ}$ (P3) respectively (Fig. 2). Nucleus used for the present study was prepared using metal templates, by adopting the method developed by Anil et al. (2003). For standardization and replication, flat-circular shaped nuclei were prepared using shell cement material; with a diameter of $5 \mathrm{~mm}$ and thickness of $2 \mathrm{~mm}$ (Fig. 5) and implanted in both shell valves. Implantation was done following the method described by Anil et al. (2007).

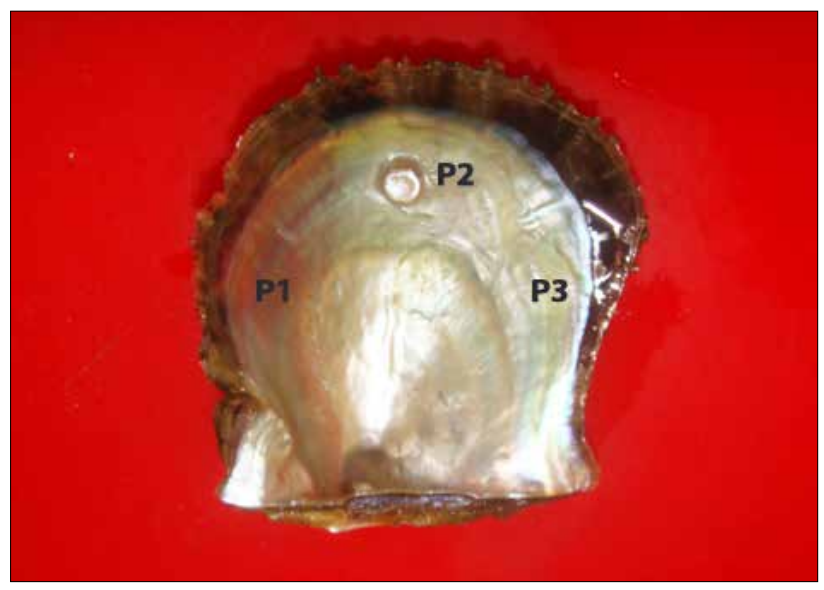

Fig. 2. Post monsoon nacre coating in $P 2$ position, with $P 1, P 2 \& P 3$ positions marked on left valve 
Each treatment was repeated in 10 oysters. After implantation, the oysters were stocked in box cages of $50 \times 50 \times 12 \mathrm{~cm}$ with a mesh size of $25 \mathrm{~mm}$, hung in wooden raft moored at a depth of $7 \mathrm{~m}$ in Vizhinjam bay and reared for 50 days.

After a period of 50 days, the implanted oysters were sacrificed and the nacre coated nucleus (mabe pearl) ( Fig. 2, 3 \& 4) was

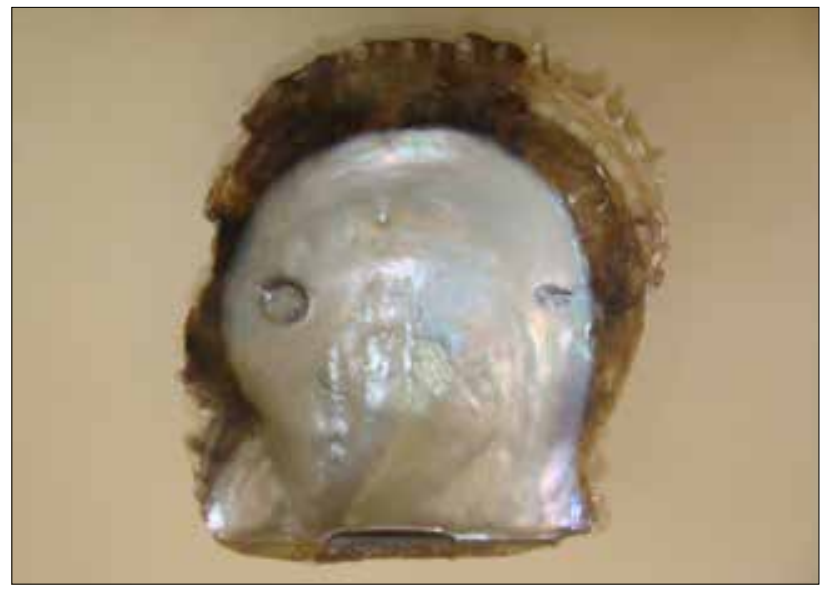

Fig. 3. Monsoon coating of nacre in P1 position.

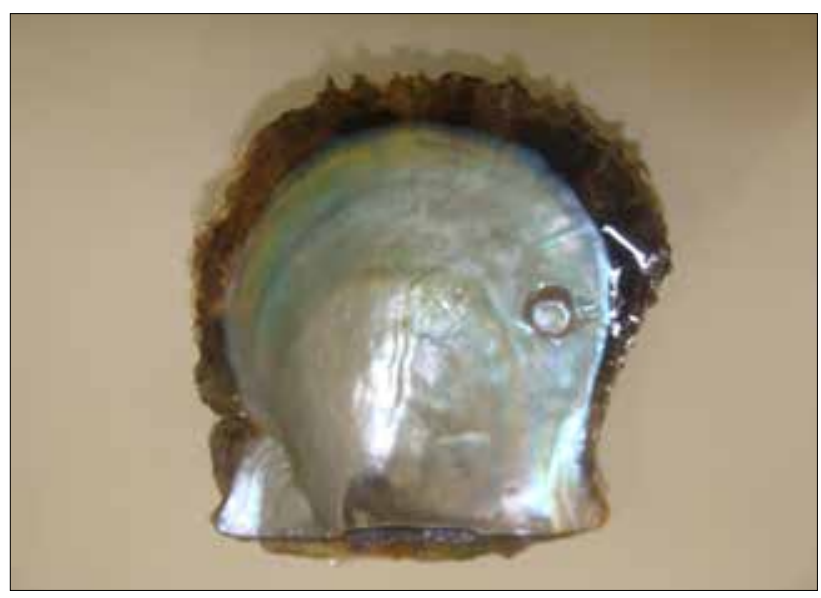

Fig. 4. Monsoon nacre coating in P3 position.

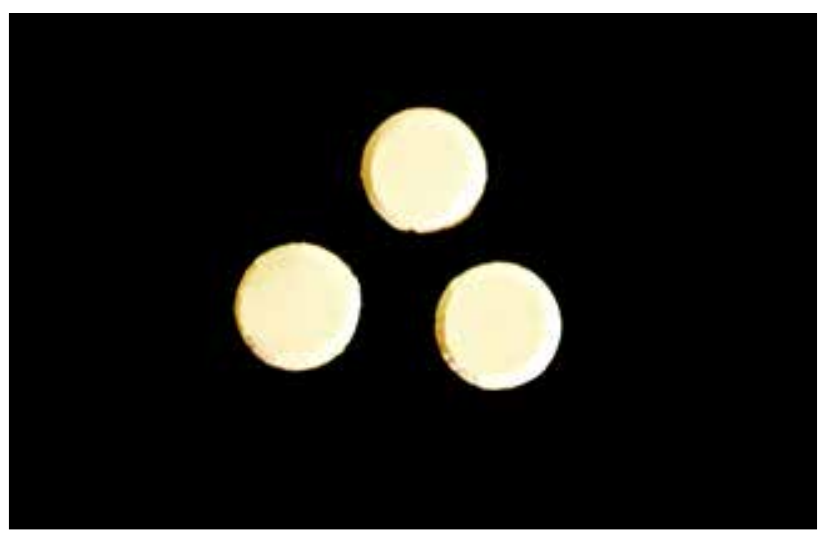

Fig. 5. Nuclei used for implantation.

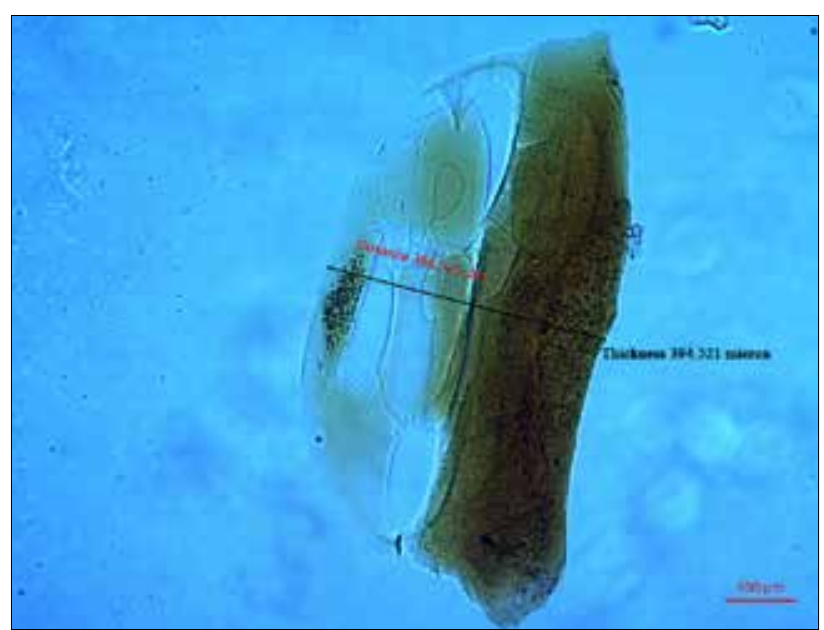

Fig. 6. Photomicrograph of nacre coating (c. s).

cut using a saw and the coated nacre was separated using a fine pointed needle from the nucleus. The central srip passing through the centre of the nacre plate of $2 \mathrm{~mm}$ width was taken using a fine scissors. This was embedded in the wax horizontally so as to take cross section (c.s) of the nacre. The nacre embedded wax block is trimmed off carefully and sections were cut using rotary microtome (LEICA RM 2235). The thickness of the nacre (Fig. 6) secreted in three positions viz., P1, P2, and P3 was measured in microns using an Axiocam camera fitted to Carl Zeiss Lab. A1 microscope (ERC 5s).

\section{Influence of hydrological parameters}

Fortnightly data on the hydrology of Vizhinjam waters was recorded during the experimental period, in order to study the influence of water quality parameters on nacre secretion of oysters. Water quality parameters including atmospheric and water temperature $\left({ }^{\circ} \mathrm{C}\right)$, salinity (ppt) and $\mathrm{pH}$ were recorded at the site. Water samples were collected and the hydrological parameters viz., turbidity, ammonia, nitrite, nitrate, phosphate, silicate, dissolved oxygen, primary productivity and chlorophyll a were analysed using standard techniques. The temperature was measured using a thermometer, salinity by means of handheld refractometer; ATAGO and $\mathrm{pH}$ were measured with compact $\mathrm{pH}$ meter; LAQUA twin (Horiba Scientific). Turbidity was recorded using nephelometer. Ammonia, nitrite, nitrate, phosphate, and silicate were checked using testkits (MERCK) by adopting photometric method (NOVA 60, Spectroquent). Dissolved oxygen was analyzed by using the Winkler method (Strickland and Parsons, 1972). Primary productivity was recorded using the light and dark bottle method and Chlorophyll a concentration was analyzed with UV Visible Spectrophotometer (Evolution 201) (Strickland and Parsons, 1972).

Experiments were carried out in three seasons namely pre monsoon (February - May), monsoon (June - August) and post monsoon (September - January). 


\section{Results}

Nacre coating thickness in position $\mathrm{P} 1$ in three seasons: Thickness of nacre coating in position P1 during the three seasons showed that post monsoon coating was higher (238.35 $\pm 81.06 \mu$ in the left valve and $319.96 \pm 96.52 \mu$ in the right valve in 50 days) than the other two seasons. P1 showed comparatively low coating rate during the monsoon (110.18 $\pm 18.11 \mu$ per 50 day rearing period , $2.20 \pm 0.36 \mu$ per day rearing period in left valve; $124.11 \pm 22.52 \mu$ per 50 day rearing period, $2.48 \pm 0.45 \mu$ per day rearing period in right valve) and pre monsoon seasons (124.37 $\pm 11.01 \mu$ per 50 day rearing period, $2.49 \pm 0.22 \mu$ per day rearing period in left valve; $114.53 \pm 17.22 \mu$ per 50 day rearing period, $2.29 \pm$ $0.34 \mu$ per day rearing period in right valve). One-way analysis of variance (ANOVA) was conducted for the rate of nacre coating for the $\mathrm{P} 1$ position during the three seasons and results are highly significant at $p<0.001$ for both right and left valve (Table 1).

Nacre coating thickness in position $\mathrm{P} 2$ in three seasons: Measurement of nacre coating in the $\mathrm{P} 2$ position was highest in post monsoon season (379.97 $\pm 115.83 \mu$ per 50 days and $6.79 \pm 2.07 \mu$ per day rearing period) in left valve and $(365.12 \pm 91.69 \mu$ per 50 days and $6.52 \pm$ $1.64 \mu$ per day rearing period) in right valve. Coating rate was lowest during the pre monsoon season $(151.35 \pm 14.83$ $\mu$ per 50 days and $3.03 \pm 0.30 \mu$ per day rearing period) in right valve and $134.12 \pm 40.26 \mu$ per 50 days and 2.68 $\pm 0.81 \mu$ per day rearing period) in right valve. Results of the one way ANOVA for the rate of nacre coating in the P2 position was statistically significant for both right and right valves $(p<0.001)$.

Nacre coating thickness in position P3 in three seasons: In the position $\mathrm{P} 3$ also, the thickness of nacre coat was maximum during the post monsoon; $156.65 \pm 35.16 \mu$ per 50 days, $2.80 \pm 0.63 \mu$ per day rearing period (left valve) and $221.47 \pm 46.84 \mu$ per 50 days, $3.95 \pm 0.84 \mu$ per day rearing period (right valve). Compared to post monsoon and monsoon; pre monsoon nacre coat showed the lowest thickness. One way ANOVA test results for the rate of nacre coating in the P3 position was statistically significant in left $(p<0.05)$ and right valve $(p<0.001)$.

\section{Comparison of nacre thickness between three positions during Pre monsoon season: Measurements} of the nacre coat thickness during pre monsoon period was highest for the position P2 viz., $151.35 \pm 14.83 \mu$ per 50 days and $3.03 \pm 0.30 \mu$ per day (left valve) and $134.12 \pm$ $40.26 \mu$ per 50 days and $2.68 \pm 0.81 \mu$ per day (right valve). The lowest coating was observed in the position P3 with a thickness of $2.19 \pm 0.17 \mu$ per day rearing (right valve) and $2.23 \pm 0.49 \mu$ per day rearing period (right valve). Results of one way ANOVA for the rate of ncre coat in left valve showed higher significance $(p<0.001)$ than the right valve (Table 2$)$.

\section{Comparison of nacre thickness between three positions during Monsoon season: Compared to $\mathrm{P} 1$ and}

Table 1. Analysis of Variance (One Way ANOVA) of nacre coating rate in positions P1, P2 and P3 in P. fucata during three seasons.

\begin{tabular}{|c|c|c|c|c|c|c|c|c|c|c|}
\hline \multirow{2}{*}{ Parameter } & \multirow{2}{*}{ Season } & \multicolumn{3}{|c|}{ P1 } & \multicolumn{3}{|c|}{$\mathrm{P} 2$} & \multicolumn{3}{|c|}{ P3 } \\
\hline & & Mean & $\pm S D$ & $F$ value & Mean & $\pm S D$ & $F$ value & Mean & $\pm S D$ & F value \\
\hline \multirow{3}{*}{ Nacre: Left valve rate/ day $(\mu)$} & Pre Monsoon & 2.49 & 0.22 & \multirow{3}{*}{$16.314^{\star *}$} & 3.03 & 0.30 & \multirow{3}{*}{$27.643^{\star *}$} & 2.19 & 0.17 & \multirow{3}{*}{$5.150^{\star}$} \\
\hline & Monsoon & 2.20 & 0.36 & & 3.16 & 0.76 & & 2.26 & 0.47 & \\
\hline & Post Monsoon & 4.26 & 1.45 & & 6.79 & 2.07 & & 2.80 & 0.63 & \\
\hline \multirow[t]{3}{*}{ Nacre: Right valve rate / day $(\mu)$} & Pre Monsoon & 2.29 & 0.34 & \multirow{3}{*}{$33.706^{\star \star}$} & 2.68 & 0.81 & \multirow{3}{*}{$34.170^{\star *}$} & 2.23 & 0.49 & \multirow{3}{*}{$21.158^{\star \star}$} \\
\hline & Monsoon & 2.48 & 0.45 & & 2.79 & 0.93 & & 2.44 & 0.56 & \\
\hline & Post Monsoon & 5.71 & 1.72 & & 6.52 & 1.64 & & 3.95 & 0.84 & \\
\hline
\end{tabular}

${ }^{*} \mathrm{P}<0.05 ;{ }^{* *} \mathrm{P}<0.001$

Table 2. Analysis of Variance (One Way ANOVA) of seasonal nacre coating rate in $P$. fucata in three positions

\begin{tabular}{|c|c|c|c|c|c|c|c|c|c|c|}
\hline \multirow{2}{*}{ Parameter } & \multirow{2}{*}{ Group } & \multicolumn{3}{|c|}{ Pre Monsoon } & \multicolumn{3}{|c|}{ Monsoon } & \multicolumn{3}{|c|}{ Post Monsoon } \\
\hline & & Mean & $\pm S D$ & F value & Mean & $\pm S D$ & F value & Mean & $\pm S D$ & F value \\
\hline \multirow{2}{*}{ Nacre: Left valve / day $(\boldsymbol{\mu})$} & P 1 & 2.49 & 0.22 & \multirow{2}{*}{$32.680^{\star \star}$} & 2.20 & 0.36 & \multirow{2}{*}{$9.345^{* *}$} & 4.26 & 1.45 & \multirow{2}{*}{$18.045^{* *}$} \\
\hline & P 3 & 2.19 & 0.17 & & 2.26 & 0.47 & & 2.80 & 0.63 & \\
\hline \multirow{2}{*}{ Nacre: Right valve / day $(\boldsymbol{\mu})$} & P 1 & 2.29 & 0.34 & \multirow{2}{*}{1.801} & 2.48 & 0.45 & \multirow{2}{*}{0.793} & 5.71 & 1.72 & \multirow{2}{*}{$8.126^{* *}$} \\
\hline & P 3 & 2.23 & 0.49 & & 2.44 & 0.56 & & 3.95 & 0.84 & \\
\hline
\end{tabular}

${ }^{\star *} \mathrm{P}<0.001$ 
P3, maximum nacre coat during monsoon season was observed in the position P2 with a thickness of $157.90 \pm 37.78 \mu$ per 50 days and $3.16 \pm 0.76 \mu$ per day (left valve) and $139.40 \pm$ $46.51 \mu$ per 50 days and $2.79 \pm 0.93 \mu$ per day (right valve). Nacre coating rate in left valve showed highly significant $F$ value at $(p<0.001)$ than the right valve.

\section{Comparison of nacre thickness between three positions during Post monsoon season: Position} P2 showed the highest thickness in nacre coat during post monsoon rearing period also, with a thickness of $379.97 \pm$ $115.83 \mu$ in 50 days and $6.79 \pm 2.07 \mu$ per day (left valve) and $365.12 \pm 91.69 \mu$ in 50 days and $6.52 \pm 1.64 \mu$ per day (right valve). But the lowest coating rate was observed in the position $\mathrm{P} 3$ with a per day coating rate of $2.80 \pm 0.63$ $\mu$ (left valve) and $3.95 \pm 0.84 \mu$ (right valve). Results of the one way ANOVA tests showed significant variation in the nacre coating rate in the three positions during post monsoon season $(p<0.001)$ than the other two seasons in both right and left valves.

\section{Comparison of nacre thickness between right and} left valves of $P$. fucata: In general no specific difference was observed on the nacre coat rate in between the right and left valves whereas in certain oysters, right valve showed high nacre coat rate than the left valve (Table 3).

Table 3. Average thickness of nacre coat in $\mu \mathrm{m}$ in right and left valves of $P$. fucata during the present study.

\begin{tabular}{lllllll}
\hline \multirow{2}{*}{$\begin{array}{l}\text { Position/ } \\
\text { interval }\end{array}$} & \multicolumn{3}{c}{ Pre monsoon } & \multicolumn{2}{c}{ Monsoon } & \multicolumn{2}{c}{ Post Monsoon } \\
\cline { 2 - 7 } & $\begin{array}{l}\text { Left valve } \\
(\mu)\end{array}$ & $\begin{array}{l}\text { Right } \\
\text { valve }(\mu)\end{array}$ & $\begin{array}{l}\text { Left valve } \\
(\mu)\end{array}$ & $\begin{array}{l}\text { Right } \\
\text { valve }(\mu)\end{array}$ & $\begin{array}{l}\text { Left valve } \\
(\mu)\end{array}$ & $\begin{array}{l}\text { Right } \\
\text { valve }(\mu)\end{array}$ \\
\hline P1/day & 2.48 & 2.29 & 2.20 & 2.48 & 4.25 & 5.71 \\
\hline P2/day & 3.02 & 2.68 & 3.15 & 2.78 & 6.78 & 6.51 \\
\hline P3/day & 2.19 & 2.27 & 2.25 & 2.43 & 2.79 & 3.95
\end{tabular}

Seasonal variation in hydrological parameters of Vizhinjam waters: Water quality parameters including water temperature, salinity, phosphate, silicate, dissolved oxygen and chlorophyll a showed significant variations during the three seasons. Water temperature was lowest in monsoon (26.59 $\left.\pm 0.72^{\circ} \mathrm{C}\right)$ compared to post monsoon $\left(28.14 \pm 1.13^{\circ} \mathrm{C}\right)$ and pre monsoon $\left(29.33 \pm 0.97^{\circ} \mathrm{C}\right)$. Salinity showed a decreasing trend during the monsoon season and the lowest was recorded during the month of July $(27.15 \mathrm{ppt})$ due to the south west monsoon. Nutrients such as silicate $(0.76 \pm 0.05 \mathrm{mg} / \mathrm{l})$ and phosphate $(0.12 \pm 0.04 \mathrm{mg} / \mathrm{l})$, productivity (NPP of 204.40 $\pm 45.86 \mathrm{mgC} / \mathrm{m}^{3} /$ day and GPP of $361.40 \pm 96.92 \mathrm{mgC} / \mathrm{m}^{3} /$ day) along with chlorophyll a concentration $(2.79 \pm 0.13 \mathrm{mg} /$ $\left.\mathrm{m}^{3}\right)$ also was maximum during the post monsoon months. Not much variation was noted in nitrate $(0.06 \pm 0.00 \mathrm{mg} / \mathrm{l})$ and nitrite $(0.05 \pm 0.00 \mathrm{mg} / \mathrm{l})$ concentration throughout the pre monsoon and monsoon months; $0.04 \pm 0.00 \mathrm{mg} / \mathrm{l}$ in post monsoon months ) levels during the three seasons. The dissolved oxygen levels were found as $3.65 \pm 0.12 \mathrm{mg} / \mathrm{l}, 3.99$ $\pm 0.04 \mathrm{mg} / \mathrm{l}, 4.05 \pm 0.24 \mathrm{mg} / \mathrm{l}$ during monsoon, pre monsoon and post monsoon respectively.

Nacre coating in relation to the hydrology of Vizhinjam waters: Correlation analysis was done for nacre thickness of three seasons in relation to hydrological parameters and the results were shown in Table 4. Parameters such as silicate, net primary production and chlorophyll a showed significant correlation to rate of nacre coating $(p<0.05)$. Effect of other parameters were found not statistically significant.

\section{Discussion}

The present study showed that there is seasonal variation in the nacre coating in $P$. fucata. The highest rates were recorded during the post monsoon, whereas lowest rates were recorded during the pre monsoon months. Since the spawning period for $P$. fucata corresponds with the southwest monsoon; major part of the energy is utilized for the gonadal maturation and may be resulting in a low rate of nacre coating during pre monsoon months. In Vizhinjam waters, gonad maturation was found related to the higher temperature (Appukuttan, 1987). Temperature is one of the key factors which regulate bivalve reproduction (Sastry, 1979; Youn and Young, 2003). Pre monsoon period coincided with the peak breeding season of P. fucata; the maximum water temperature $\left(29.33 \pm 0.97^{\circ} \mathrm{C}\right)$ recorded during this period aids in the gonadal development.

The lustrous quality of a pearl is determined by the thickness of the nacre (Hollyer, 1984; Kripa et al., 2007). Comparing the three positions, position P2 recorded the highest rate of nacre coating with a good sheen. Position P2 is located in the mantle region with maximum area whereas position $\mathrm{P} 1$ lies near the visceral mass and position P3 is close to the foot and gonads. The wide marginal mantle region supports the current result on position P2 with better coating rate and good nacre quality.

Saucedo et al. (1998) opined that pallial zone in the central band of a bivalve is the best site for implantation of nuclei but a high rate of nacre secretion can lead to the production of baroque pearl. During the present study also though zone P2 gave the best coating but in some cases, the nucleus got over coated and over coating can lead to loss of finer details when implanted with real mabe pearl nucleus containing shapes of figurines. Monteforte et al. (1994) also stated the merit of superior quality pearls from the central pallial sector. During the experiment trials, P2 also showed imperfections in those which are implanted near to the margin of valves as reported by Saucedo et al. (1998). 
Table 4. Multivariate Pearson's correlation analysis of nacre coat rate of $P$. fucata and hydrological parameters.

\begin{tabular}{|c|c|c|c|c|c|c|c|c|c|c|c|c|c|c|c|c|}
\hline Parameters & 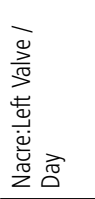 & 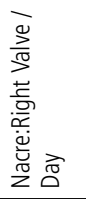 & 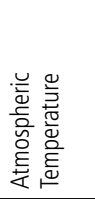 & 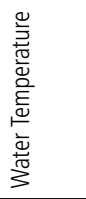 & 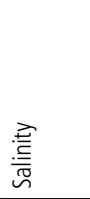 & I & $\frac{\sqrt{\frac{1}{0}}}{\frac{0}{0}}$ & 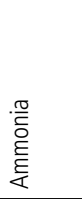 & . & 产 & $\begin{array}{l}\frac{0}{0} \\
\frac{\pi}{0} \\
\frac{0}{n} \\
\frac{0}{2} \\
\frac{c}{2}\end{array}$ & 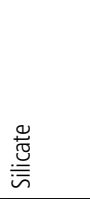 & 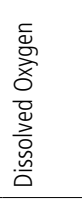 & 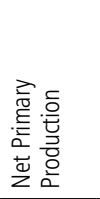 & 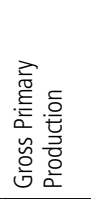 & 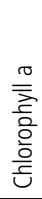 \\
\hline $\begin{array}{l}\text { Nacre:Left } \\
\text { Valve /Day }\end{array}$ & 1 & & & & & & & & & & & & & & & \\
\hline $\begin{array}{l}\text { Nacre:Right } \\
\text { Valve /Day }\end{array}$ & $0.614^{\star *}$ & 1 & & & & & & & & & & & & & & \\
\hline $\begin{array}{l}\text { Atmospheric } \\
\text { Temperature }\end{array}$ & -0.152 & 0.008 & 1 & & & & & & & & & & & & & \\
\hline $\begin{array}{l}\text { Water } \\
\text { Temperature }\end{array}$ & 0.070 & 0.090 & $0.712^{\star \star}$ & 1 & & & & & & & & & & & & \\
\hline Salinity & 0.364 & 0.322 & 0.173 & 0.441 & 1 & & & & & & & & & & & \\
\hline $\mathrm{pH}$ & 0.459 & 0.484 & 0.418 & 0.255 & 0.14 & 1 & & & & & & & & & & \\
\hline Turbidity & 0.569 & 0.505 & -0.327 & 0.007 & 0.065 & 0.269 & 1 & & & & & & & & & \\
\hline Ammonia & -0.107 & -0.204 & 0.272 & -0.046 & -0.400 & 0.024 & -0.352 & 1 & & & & & & & & \\
\hline Nitrite & -0.279 & -0.516 & 0.399 & 0.377 & -0.093 & 0.315 & -0.148 & 0.027 & 1 & & & & & & & \\
\hline Nitrate & 0.427 & 0.557 & -0.035 & -0.084 & 0.302 & 0.263 & 0.339 & 0.209 & $-0.668^{*}$ & 1 & & & & & & \\
\hline Phosphate & 0.161 & 0.520 & -0.079 & -0.231 & -0.013 & -0.118 & 0.034 & -0.141 & $-0.732^{\star \star}$ & 0.331 & 1 & & & & & \\
\hline Silicate & 0.538 & $0.590^{\star}$ & -0.493 & -0.441 & 0.000 & -0.023 & 0.301 & -0.095 & $-0.806^{\star *}$ & 0.559 & $0.713^{* \star}$ & 1 & & & & \\
\hline $\begin{array}{l}\text { Dissolved } \\
\text { Oxygen }\end{array}$ & 0.461 & 0.459 & 0.472 & 0.569 & 0.508 & $0.725^{\star \star}$ & 0.241 & -0.148 & 0.325 & 0.113 & -0.008 & -0.066 & 1 & & & \\
\hline $\begin{array}{l}\text { Net Primary } \\
\text { Production }\end{array}$ & $0.602^{*}$ & 0.415 & -0.306 & 0.003 & -0.188 & 0.156 & $0.767^{\star *}$ & -0.159 & -0.170 & 0.166 & 0.186 & 0.522 & 0.105 & 1 & & \\
\hline $\begin{array}{l}\text { Gross Primary } \\
\text { Production }\end{array}$ & 0.564 & 0.423 & -0.071 & -0.014 & -0.206 & $0.580^{*}$ & $0.704^{*}$ & -0.159 & 0.186 & 0.026 & 0.084 & 0.269 & 0.404 & $0.805^{\star \star}$ & 1 & \\
\hline Chlorophyll a & 0.506 & $0.589^{*}$ & -0.300 & -0.283 & -0.363 & 0.062 & 0.416 & -0.141 & -0.405 & 0.017 & $0.645^{*}$ & $0.667^{*}$ & 0.028 & $0.684^{*}$ & $0.611^{*}$ & 1 \\
\hline
\end{tabular}

Results of the current study did not show any specific variation in the rate of nacre coating among the two valves of $P$. fucata. Saucedo et al. (1998) conducted mabe implantation experiments in Pinctada mazatlantica and Pteria sterna and had neither noted any particular difference in the nacre coat between different valves. Monteforte et al. (1994) also reported the same observations in $P$. mazatlantica and $P$. sterna. The preferred shell for nucleus implantation is the left valve due to the larger area available for nucleus implantation.

Alagarswami (1987) had stated that the time of pearl harvest depends upon the rate of nacre deposition and the mineral lamellae thickness lay down in different seasons. During the present study, the image pearl nacre coating showed metallic lustre with golden hues, and post monsoon showed better quality compared to monsoon and pre monsoon period. $P$. fucata possesses a well developed golden yellow coloured nacreous layer with bright, metallic lustre (Rao and Rao, 1974) while other Pteriidae species (Pinctada mazatlantica and Pteria sterna) also exhibit different colours and hues, from silvery, golden, purple, blue and grey ( $P$. sterna) to blue-grey and dark-grey ( $P$. mazatlantica) in the central mantle sector with a homogenous and thicker nacre coating (Saucedo et al.,1998).
Results of the experiment trials indicated that nacre coating thickness is also correlated to environment parameters. The farming site of oysters which indirectly reflects the environment condition affects the oyster survival and pearl quality (Gervis and Sims, 1992; Kripa et al., 2007). Rao and Rao (1974) and Cahn (1949) also reported favourable environmental conditions of water temperature, salinity and light intensity influence the quality of pearls. Le et al., 2016 detailed on the key role played by environment factors of the culture site in determining the size of the cultured pearl and shell growth in $P$. margaretifera. Chin-Long et al., 2014, also reported on the impact of seasons in the nucleus retention rate in $P$. margaretifera stated that grafting in the autumn is better than that in spring season in which the temperature is higher. Studies conducted on relation of molluscan shell nacre ultra-structure with environmental temperature and pressure (Ian et al., 2012) also revealed strong correlation between crystal misorientations and environmental temperature and the result further verified by means of secondary ion mass spectrometry measurements of in situ $\delta^{18} 0$ in the nacre of the shell.

Lowest water temperature $\left(26.59 \pm 0.72^{\circ} \mathrm{C}\right)$ was recorded during the monsoon months (June to August) due to arrival of 
south west monsoon. Since salinity decreases with precipitation; it lowers the concentration up to an average $28.85 \mathrm{ppt}$ during monsoon season with a minimum pH of 7.85. It is well known that lower temperature reduces the metabolic activities which in turn might result in lower nacre coating rate during monsoon months. The change in the sea water temperature is correlated to the change in the expression pattern of the calcification-related genes (nacrein, n16, n19), irr and hsp70 and is linked to the changes in specific metabolic rates (Liu et al., 2014).

Southwest monsoon, as well as northeast monsoon, brings a lot of nutrients into the coastal waters which are also reflected in the present results. Coastal upwelling also is a key factor in the primary production during the southwest and northeast monsoon. Along the Southwest coast of India, during monsoon months cold nutrient - rich bottom water comes to the surface leading to the lowering of surface and coastal temperatures which in turn improves the nutrient content of the coastal waters (Kripa, 2017). Rao et al., 1992, reported the occurrence of peak plankton biomass during the peak southwest monsoon during upwelling and post monsoon months after the upwelling period. Upwelling increases the nutrient content in the euphotic zone there by increasing the productivity (Sharma, 1978). These factors support the present study results that post monsoon and monsoon months enhance the faster rate of nacre secretion than pre monsoon months. It was found that nacre coating during the mabe pearl production is faster in Vizhinjam waters and during the present study, post monsoon in which the water temperature is optimum favours lustrous quality pearl with thinner layers. Gervis and Sims, 1992 also opined that growth of pearls decreased with lower temperature resulting in fine quality nacre with thinner layers. Latchere et al., 2018, studied on the influence of water temperature on the last stages of cultured pearl mineralization from the black-lip pearl oyster $P$. margaritifera and revealed that higher temperature stimulate shell and pearl deposition rates but low water temperature minimizes the deposition rate of nacre tablets, improving lustrous pearls with less imperfection.

But comparing to monsoon months, present study results showed that chlorophyll a concentration was highest during the post monsoon period; which reflects phytoplankton abundance and productivity. So the higher productivity might have played a decisive role in the higher nacre coating rate during the post monsoon season compared to monsoon and pre monsoon months.

Previous studies on the seasonal variation in rainfall, salinity, temperature, light penetration, $\mathrm{pH}$, dissolved oxygen content and availability of nutrients from Vizhinjam Bay during one year period of 1977-78 (Dharmaraj et al., 1980; Appukuttan, 1987) confirms that nutrient values are high during the post monsoon

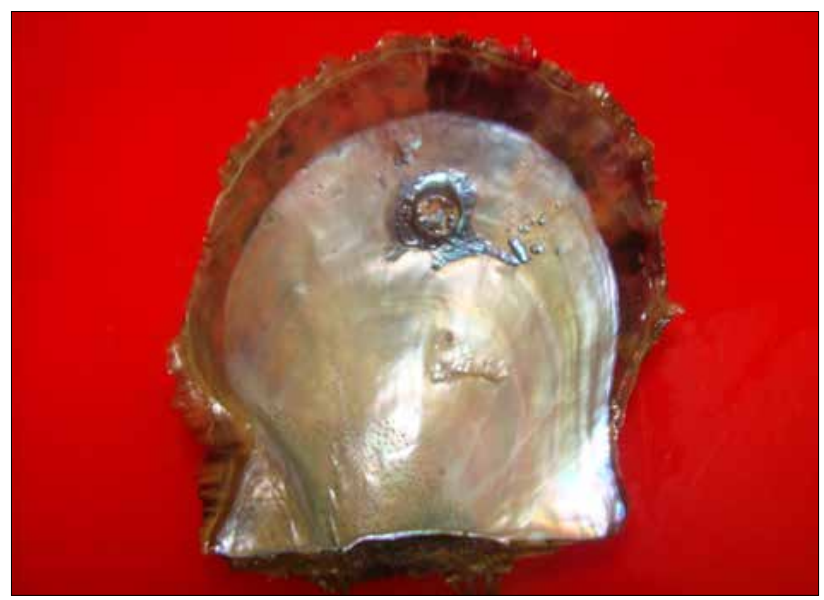

Fig. 7. Pre-monsoon blemish over the implanted nuclei

period. Seasons along with water temperature are involved in the variations in shape and growth rate of nacre tablets $i e$., typical nanoglobular structure comprising an aragonite core bounded by amorphous calcium carbonate together with organic macromolecules during the course of a year (Wada, 1972; Rousseau and Rollion-Bard, 2012) and which also corroborate the present findings.

So the present study reveals that post monsoon is the best season for implanting image pearls and keeping oysters in the period for more than 50 days lead to over coating of the image pearls resulting in loss of details. The coating was less during the pre monsoon months with lot of spots and blemishes (Fig. 7) which coincide with the reproductive season, gamete maturation and spawning along the southwest coast of India. Also, the temperature of waters in different seasons influence nacre coating rate in oysters.

\section{Acknowledgements}

We express our sincere gratitude to the University of Kerala for the research grant provided. Also, we are grateful to the Director, ICAR-Central Marine Fisheries Research Institute for providing facilities for the work.

\section{References}

Alagarswami, K. 1987. Cultured pearls - production and quality. CMFRI Bulletin - Pearl culture, 39. p. 107 - 111.

Alagarswami, K. 1991. Production of cultured pearls. Indian Council of Agricultural Research Publication, New Delhi, India.112 pp.

Anil, M. K., Andrews, Joseph., K. T. Thomas, K. K. Appukuttan and N. Ramachandran. 2003. Experimental mabe/image pearl production at Vizhinjam. Fishing Chimes 23 (10\& 11). p. $49-50$.

Anil, M. K., Andrews, Joseph., K. T. Thomas, Rayer and V.Sekhar. 2007. Marine image pearls: Designed by man; created by nature. Fishing Chimes, 26 (10): 16-18.

Appukuttan, K. K. 1987. Pearl oyster culture in Vizhinjam Bay. CMFRI Bulletin - Pearl culture, 39. p. 54 - 61

Cahn, A. 1949. Pearl culture in Japan. United States Dept. Interior Fish Wildlife Service. Fishery leaflet, 357: 1-91.

Chin-Long, Ky., N. Molinari., E. Moe., and S. Pommier, 2014. Impact of season and grafter skill on nucleus retention and pearl oyster mortality rate in Pinctada margaritifera aquaculture. Aquacult Int, 22:1689-1701. 
Coeroli, M. and K. Mizuno. 1985. Study of different factors having an influence upon the pearl production of the black lip pearl oyster. Proc. 5th Coral Reef Congress, Tahiti, 5: 551 - 556.

Dharmaraj, K., N. B. Nair and K. G. Padmanabhan. 1980. Studies on the hydrobiological features of the Vizhinjam Bay. J. Mar. Ass. Sym. Coastal Aquaculture, 30: p. 19.

Dharmaraj, S. and N. Sukumaran, 2003a. Role of post operative culture period on cultured pearl production in the Indian pearl oyster Pinctada fucata (Gould). Abstracts of the First Indian Pearl Congress and Exposition. Central Marine Fisheries Research Institute, Cochin, India, p.57. 5 - 8 February 2003.

Dharmaraj, S. and N. Sukumaran. 2003 b. Effect of oyster size on cultured pearl production in the Indian pearl oyster Pinctada fucata (Gould). Abstracts of the First Indian Pearl Congress and Exposition. Central Marine Fisheries Research Institute, Cochin, India, 58:5-8.

Gervis, M. H. and N. A. Sims. 1992. The biology and culture of pearl oysters (Bivalvia: Pteridae) ICLARM Studies and Reviews. 21, Overseas Development Administration, UK and ICLARM, Manila, 49 pp.

Hollyer, J. 1984. Pearls - jewels of the sea. Infofish Mark. Dig. 5:32 - 34.

lan, C. Olson., Reinhard, Kozdon., John, W. Valley., Pupa U., P. A. Gilbert., 2012. Mollusk shell nacre ultrastructure correlates with environmental temperature and pressure. J. Am. Chem. Soc., 134 (17): 7351 - 7358.

Jagadis, I., B. Ignatius, K. Ilangovan, A. C. C. Victor, A. Chellam, and V. Rani. 2003. Pearl production in Pinctada fucata under two culture systems in the inshore waters of Mandapam, Gulf of Mannar. Abstracts of the First Indian Pearl Congress and Exposition. Central Marine Fisheries Research Institute, Cochin, India, p. 70.5 - 8

Kripa, V., K. S. Mohamed, K. K. Appukuttan and T. S. Velayudhan. 2007. Production of Akoya pearls from the Southwest coast of India. Aquaculture, 262: 347-354.

Kripa,V., K. J. Abraham, C. L. Libini, T. S. Velayudhan, P. Radhakrishnan, K. S. Mohamed, and M. Mohan Joseph. 2008. Production of designer mabe Pearls in the black-lipped pearl oyster, Pinctada margaritifera, and the winged pearl oyster, Pteria penguin, from Andaman and Nicobar Islands, India. Journal of the World Aquaculture Society 39 (1): 131 - 137.

Kripa, V. 2017. Role of environmental variables on spawning and recruitment of small pelagics in an upwelling system. In: Course Manual. Summer school on advanced methods for fish stock assessment and fisheries management. Lecture Note Series No. 2/2017. CMFRl; Kochi, p. 289 - 295.

Latchere, O., V. Mehn, N. Gaertner - Mazouni, Le, G. Moullac, J. Fievet, C. Belliard, et al. (2018). Influence of water temperature and food on the last stages of cultured pearl mineralization from the black-lip pearl oyster Pinctada margaritifera. PLOS ONE, 13(3): e0193863. https://doi.org/10.1371/ journal.pone.0193863".

Le, Pabic, Lore, Parrad Sophie, Sham Koua, Manaarii, Seiji Nakasai, Saulnier Denis, Devaux and Ky Chin-Long. 2016. Culture site dependence on pearl size realization in Pinctada margaritifera in relation to recipient oyster growth and mantle graft biomineralization gene expression using the same donor phenotype. Estuarine, Coastal and Shelf Science, 182 (Part B): 294-303.

Liu, Wenguang., Huang, Xiande., Lin, Jianshi., He, and Maoxian., 2014. Effect of temperature on gene expression in the pearl oyster Pinctada fucata. J. Ocean Univ. China (Oceanic and Coastal Sea Research), 13 (3): 509 - 515.
Marthe, Rousseau., Claire and Rollion-Bard. 2012. Influence of the depth on the shape and thickness of nacre tablets of Pinctada margaritifera pearl oyster, and on oxygen isotopic composition. Minerals, 2: $55-64$.

Mizuno, K. 1983. Etude de la greffe de I'huitreperiere a levresnoires (Pinctada margaritifera). Rapport No. 1. EVAAM, Tahiti, French Polynesia, 34 pp.

Mohamed, K. S., K. K. Appukuttan, V. Kripa, T. S. Velayudhan, P. S. Aloycious and Leena, Ravi. 2003. Production of Mabe pearls in Pinctada fucata. In: Book of Abstracts, First Indian Pearl Congress and Exposition, Cochin, p. 97 - 98.

Mohamed, K.S., V. Kripa, P. Radhakrishnan, P. S. Alloycious, Leena, Ravi, K. P. S. Koya, and K. K. Appukuttan. 2011. Mabe Pearls:A simple way to value added pearls (Pamphlet). Central Marine Fisheries Research Institute, Cochin.

Monteforte, M., H. Bervera, S. Morales, V. Perez, P. Saucedo and H. Wright. 1994. Results of the production of cultured pearls in Pinctada mazatlantica and Pteria sterna from Bahia de La Paz, South Baja California. Mexico (Abstract Pearls '94). Journal of Shellfish Research, 13:344 - 345.

Rao, K. V. and K. S. Rao. 1974. Pearl oysters. In: The Commercial Molluscs of India, Bull. Cent. Mar. Fish, Res. Inst., 25: 84-106.

Rao, D. S., C. P. Ramamirtham, A. V. S. Murty, S. Muthusamy, N. P. Kunhikrishnan and L. R. Khambadkar. 1992. Oceanography of the Arabian Sea with particular reference to the southwest monsoon. CMFRI Bulletin, 45: 4 - 8.

Sastry, A. N. 1979. Pelecypoda (excluding Ostreidae). In: Giese, A.C., Pearse, J.S. (Eds.), Reproduction of Marine Invertebrates, vol. V. Academic Press, New York, 131 $195 \mathrm{pp}$.

Saucedo, P., M. Monteforte and F. Blanc. 1998. Changes in shell dimensions of pearl oysters, Pinctada mazatlantica (Hanley 1856) and Pteria sterna (Gould 1851), during growth as criteria for Mabe pearl implants. Aquacult. Res., $29: 801-814$.

Sharma, G. S. 1978. Upwelling off the Southwest Coast of India. Indian J. Mar. Sci., 7(4): $209-218$

Shirai, S. 1970. The Story of Pearls. Japan Publications Inc., Japan, 132 pp.

Strickland, J. D. H. and T. R. Parsons. 1972. A practical handbook of seawater analysis. Bulletin Fisheries Research Board of Canada, 167: 1-310.

Velayudhan, T. S., A. Chellam, S. Dharmaraj, A. C. C. Victor and H. M. Kasim. 1996. Comparison of growth and shell attributes of four generations of pearl oyster Pinctada fucata (Gould) produced in the hatchery. Indian J. Fish., 43: 69-77.

Victor, A. C. C., I. Jagadis, B. Ignatius and A. Chellam. 2003. Perspectives and problems of commercial scale pearl culture - an indicative study at Mandapam Camp, Gulf of Mannar. Abstracts of the First Indian Pearl Congress and Exposition. Central Marine Fisheries Research Institute, Cochin, India, p. 73-75.

Wada, K., 1972. Nucleation and growth of aragonite crystals in the nacre of some bivalve molluscs. Biomineralization, 6:141-159.

Wada, K. T. and A. Kamaru. 1996. Colour and weight of pearls produced by grafting the mantle tissue from a selected population for white shell colour of the Japanese pearl oyster, Pinctada fucata martensii (Dunker). Aquaculture., 142: 25-32.

Youn, Hee, Choi., Young, Jin and Chang. 2003. Gametogenic cycle of the transplanted - cultured pearl oyster, Pinctada fucata martensii (Bivalvia: Pteriidae) in Korea. Aquaculture., 220: 781-790. 